\title{
Erişkin Kalp Cerrahisinde, ABO ve Rh Kan Gruplarının İnotropik Ajan Kullanımı Üzerine Etkileri
}

\author{
Effects of ABO and Rh Blood Groups on Inotropic Agent Use in Adult Cardiac Surgery \\ Yavuz ORAK ${ }^{1}$, Adem DOGANER ${ }^{2}$
}

\author{
${ }^{1}$ Kahramanmaras Sutcu Imam University Faculty of Medicine, Department of Anesthesiology and Reanimation, Kahramanmaras, Turkey \\ ${ }^{2}$ Kahramanmaras Sutcu Imam University Faculty of Medicine, Department of Biostatistics and Medical Informatics, Kahramanmaras, Turkey
}

Amaç: Bu çalışmanın amacı, erişkin kalp cerrahisinde farklı kan gruplarında inotropik ajanların intraoperatif ve postoperatif kullanımının araştırılmasıdır.

Gereç ve Yöntemler: 15 Haziran 2017 ve 15 Kasım 2019 tarihleri arasında kardiyopulmoner bypass (CPB) uygulanan hastaların hastane bilgi yönetim sistemi kayıtlarını ve dosyalarını retrospektif olarak inceledik. Hastaların yaşı, cinsiyeti, kan grubu, tanısı, indüksiyonda fentanil ve demizolam kullanımı, CPB zamanı, kros klemp zamanı, ameliyat süresi, intraoperatif ve postoperatif inotropik ajan kullanımı, postoperatif entübasyon süresi ve yoğun bakım yatı̧s gün süresini araştırdık.

Bulgular: ABO ve RH kan grupları arasında indüksiyonda fentanil ve demizolam kullanımı, CPB zamanı, kros klemp zamanı, postoperatif entübasyon zamanı, yoğun bakım hastanede yatış günü ve ameliyat süresi açısından fark yoktu. Postoperatif dopamin kullanımı kan grubu A, B ve O'da intraoperatif kullanıma göre daha yüksekti $(\mathrm{p}=0.001, \mathrm{p}=0.014, \mathrm{p}=0.001)$. Postoperatif norepinefrin kullanımı $\mathrm{A}, \mathrm{B}$ ve $\mathrm{O}$ kan grupları arasında intraoperatif kullanıma göre daha yüksekti $(\mathrm{p}=0.001, \mathrm{p}=0.025, \mathrm{p}=0.002)$. Postoperatif nitrogliserin kullanımı kan grubu $\mathrm{O}$ 'da intraoperatif kullanıma göre daha yüksekti ( $\mathrm{p}=0.034)$. Postoperatif dopamin, norepinefrin ve nitrogliserin kullanımı $\mathrm{Rh}(+)$ grubunda intraoperatif kullanıma göre daha yüksekti $(\mathrm{p}=0.001, \mathrm{p}=0.001, \mathrm{p}=0.011)$. $\mathrm{Rh}$ (-) grubunda, postoperatif norepinefrin kullanımı intraoperatif kullanıma göre daha yüksekti $(\mathrm{p}=0.004)$. $\mathrm{Rh}(+)$ grubunda intraoperatif nitrogliserin kullanımı $\mathrm{Rh}(-)$ grubuna göre daha yüksekti ( $\mathrm{p}=0.042)$.

Sonuç: Çalışmamızda ABO ve Rh kan gruplarında inotropik ajan kullanımı farklılık gösterdi.

Anahtar Kelimeler: ABO, Rh, İnotropik ajan, Erişkin kalp cerrahisi

\begin{abstract}
Objective: The objective of this study was to investigate the intraoperative and postoperative use of inotropic agents in different blood groups in adult cardiac surgery.

Material and Methods: We retrospectively analyzed the hospital information management system records and files of patients who underwent cardiopulmonary bypass (CPB) between June 15, 2017 and November 15, 2019. We evaluated the patients' age, sex, blood group, diagnosis, use of fentanyl and demizolam in induction, CPB time, cross-clamp time, operation time, use of intraoperative and postoperative inotropic agents, postoperative intubation period, and day of intensive care hospitalization.

Results: There was no difference between the $\mathrm{ABO}$ and $\mathrm{Rh}$ blood groups in terms of use of fentanyl and demizolam in induction, $\mathrm{CPB}$ time, cross-clamp time, postoperative intubation time, day of intensive care hospitalization and duration of surgery. Postoperative dopamine use was higher in blood groups $\mathrm{A}, \mathrm{B}$, and $\mathrm{O}$ than its intraoperative use $(\mathrm{p}=0.001, \mathrm{p}=0.014, \mathrm{p}=0.001)$. Postoperative norepinephrine use was higher among $\mathrm{A}, \mathrm{B}$, and $\mathrm{O}$ blood groups than its intraoperative use $(p=0.001, p=0.025, p=0.002)$. Postoperative nitroglycerin use was higher in blood group $O$ than its intraoperative use ( $p=0.034)$. The use of postoperative dopamine, norepinephrine, and nitroglycerin was higher in the $\mathrm{Rh}(+)$ group as compared to intraoperative use $(\mathrm{p}=0.001, \mathrm{p}=0.001, \mathrm{p}=0.011)$. Postoperative norepinephrine use was higher in the $\mathrm{Rh}(-)$ group than in its intraoperative use (0.004). The use of intraoperative nitroglycerin in the $\mathrm{Rh}(+)$ group was higher as compared to the $\mathrm{Rh}(-)$ group $(\mathrm{p}=0.042)$.
\end{abstract}

Conclusion: Our study found that the use of inotropic agents was different in $\mathrm{ABO}$ and $\mathrm{Rh}$ blood groups.

Key words: $\mathrm{ABO}, \mathrm{Rh}$, inotropic agents, adult cardiac surgery

Yazışma Adresi: Yavuz ORAK, Kahramanmaraş Süţü İmam Üniversitesi Tıp Fakültesi Anesteziyoloji ve Reanimasyon ABD, Kahramanmaraş, Türkiye, Telefon: +90 (344) 300 3343, Mail: dryavuzorak@hotmail.com

ORCID No (Sirasiyla): 0000-0002-8356-6223, 0000-0002-0270-9350

Geliş tarihi: 18.08.2020

Kabul tarihi: 23.12.2010

DOI: $10.17517 /$ ksutfd. 782016 


\section{INTRODUCTION}

There may be differences in $\mathrm{ABO}$ and $\mathrm{Rh}$ blood groups in people because of their ethnicity and geography (1). According to the presence of antigens on the surface of erythrocytes, blood groups are divided into different groups (2). The ABO system is characterized by complex carbohydrate molecules with $\mathrm{A}, \mathrm{B}$, and $\mathrm{H}$ antigens, whereas the $\mathrm{O}$ allele does not encode a transferase enzyme (3). The antigens belonging to the $\mathrm{ABO}$ blood groups are found on the surface of erythrocytes and platelets; vascular epithelium cells; intestinal, cervical, and mammary gland; epithelium cells; plasma; saliva; urine; milk; and feces. The presence of Rh D antigen on erythrocytes causes individuals to be classified ' $\mathrm{Rh}$ positive, whereas its absence causes the individuals to be classified as Rh negative (4). The prevalence of ABO alleles varies among different populations. Researchers have observed a relationship between some diseases and different genotypes of $\mathrm{ABO}$ blood groups (5). In addition, research works have most frequently reported cardiovascular diseases, gastroduodenal diseases, tumors, and infections in different genotypes of ABO blood groups (6-8).

The first hours of patient care in the intensive care unit after cardiac surgery is a very crucial period because different hemodynamic changes may occur in this time. Therefore, hemodynamic monitoring, administration of inotropic drugs and vasopressors are critical check points during the assessment of perioperative cardiovascular function. Inotropes and vasopressors are the cornerstones of hemodynamic therapy. Inotropic agents are used in $30-50 \%$ of patients to improve their heart performance after open heart surgery and cardiopulmonary bypass (9-11).
The purpose of this study was to investigate the intraoperative and postoperative use of inotropic agents in different blood groups in adult cardiac surgery.

\section{MATERIAL and METHODS}

The study was planned according to the principles of the Helsinki Declaration. The Ethics Committee granted their approval for this study protocol on March 18, 2020 (2020/06$01)$. We performed our study on 192 patients who were extubated within 24 hours of cardiopulmonary bypass (CPB) surgery between June 15, 2017-November 15, 2019 in Departmant of Anesthesiolgy, Faculty of Medicine, Kahramanmaras Sutcu Imam University. Further, we retrospectively analyzed the hospital information management system records and files of these patients who underwent $\mathrm{CPB}$. We evaluated the patients' age, sex, body mass index (BMI), blood group, diagnosis, use of fentanyl and demizolam in induction, $\mathrm{CPB}$ time, cross-clamp time, operation time, use of intraoperative and postoperative inotropic agents, postoperative intubation period, and day of intensive care hospitalization.

We aimed to investigate the effects of $\mathrm{ABO}$ and $\mathrm{Rh}$ blood groups on inotropic agent use in adult cardiac surgery.

\section{Statistical Analysis}

We employed the Shapiro-Wilk test to examine the suitability of the data for normal distribution. Further, we used the Kruskal-Wallis $\mathrm{H}$ test for analyzing the comparisons among the four blood groups in the non-normally distributed variables. We used Mann-Whitney $U$ test for the comparison of two groups, and performed Wilcoxon test to compare the parameters before and after the surgery. $\mathrm{P}<0.05$ was considered statistically significant for this study. We used IBM SPSS version 22 program to evaluate the data of this study.

\section{Table 1. Demographic structures of the patients and surgery}

\begin{tabular}{|c|c|c|c|}
\hline \multicolumn{2}{|l|}{ Age } & Median (Q1-Q3) & $62(50-69)$ \\
\hline \multicolumn{2}{|l|}{ BMI } & Median (Q1-Q3) & $26(24.0-29.3)$ \\
\hline \multirow[t]{2}{*}{ Sex } & Female & $\mathrm{n}(\%)$ & $79(41.10)$ \\
\hline & Male & $\mathrm{n}(\%)$ & $113(58.9)$ \\
\hline \multirow[t]{15}{*}{ Surgery } & Aortic aneurysm & $\mathrm{n}(\%)$ & $9(4.7)$ \\
\hline & Aortic stenosis & n (\%) & $1(0.5)$ \\
\hline & ASD & $\mathrm{n}(\%)$ & $15(7.8)$ \\
\hline & Atrial myxoma & $\mathrm{n}(\%)$ & $1(0.5)$ \\
\hline & AVR & $\mathrm{n}(\%)$ & $15(7.8)$ \\
\hline & AVR+MVR & $\mathrm{n}(\%)$ & $11(5.8)$ \\
\hline & $\mathrm{AVR}+\mathrm{TVR}$ & $\mathrm{n}(\%)$ & $1(0.5)$ \\
\hline & CABG & $\mathrm{n}(\%)$ & $103(53.6)$ \\
\hline & $\mathrm{CABG}+\mathrm{AVR}$ & $\mathrm{n}(\%)$ & $3(2.0)$ \\
\hline & $\mathrm{CABG}+\mathrm{MVR}$ & $\mathrm{n}(\%)$ & $6(3.1)$ \\
\hline & $\mathrm{CABG}+\mathrm{TVR}$ & $\mathrm{n}(\%)$ & $1(0.5)$ \\
\hline & MVR & $\mathrm{n}(\%)$ & $16(8.3)$ \\
\hline & MVR+TVR & $\mathrm{n}(\%)$ & $5(2.6)$ \\
\hline & TVR & $\mathrm{n}(\%)$ & $3(1.6)$ \\
\hline & VSD & $\mathrm{n}(\%)$ & $2(1.0)$ \\
\hline
\end{tabular}

ASD, atrial septal defect; AVR, aortic valve replacement; MVR, mitral valve replacement; CABG, coroner artery bypass graft; TVR, tricuspid valve replacement; VSD, ventricular septal defect 


\section{RESULTS}

The mean age of the patients was 62 years, and the mean BMI was 26. Our study had 79 (41.10\%) female and 113 (58.90\%) male patients (Table 1).

Most of the patients had blood group A (84, $43.8 \%)$. There were higher number of patients with $\mathrm{RH}(+)(174$,
$90.6 \%$ ) than RH (-) (Table 2). We found that there was no difference among the $\mathrm{ABO}$ blood groups in terms of use of fentanyl and demizolam, CPB duration, cross-clamp time, postoperative intubation time, intensive care hospitalization time, and operation time (Table 3).

Table 2. Distribution of blood groups

\begin{tabular}{|l|l|l|l|}
\hline \multicolumn{2}{|l|}{ Blood groups } & N & $\%$ \\
\hline & A & 84 & 43.8 \\
\hline & B & 32 & 16.7 \\
\hline & AB & 11 & 5.7 \\
\hline RH & 0 & 65 & 33.9 \\
\hline RH (+) & 174 & 90.6 \\
\hline & RH (-) & 18 & 9.4 \\
\hline
\end{tabular}

Table 3. Clinical parameters according to A BO blood groups

\begin{tabular}{|c|c|c|c|c|c|c|c|c|c|c|c|c|c|}
\hline & \multicolumn{12}{|c|}{ Blood groups } & \multirow[b]{3}{*}{$\mathbf{P}$} \\
\hline & \multicolumn{3}{|c|}{$A(n=84)$} & \multicolumn{3}{|l|}{ B $(n=32)$} & \multicolumn{3}{|c|}{$A B(n=11)$} & \multicolumn{3}{|l|}{$O(n=65)$} & \\
\hline & Median & Q1 & Q3 & Median & Q1 & Q3 & Median & Q1 & Q3 & Median & Q1 & Q3 & \\
\hline $\begin{array}{l}\text { Fentanyl } \\
\text { induction } \\
(\mathrm{mcg})\end{array}$ & 250 & 200 & 350 & 250 & 200 & 350 & 250 & 200 & 300 & 300 & 250 & 362.5 & 0.48 \\
\hline $\begin{array}{l}\text { Demizolam } \\
\text { induction } \\
(\mathrm{mg})\end{array}$ & 4 & 3 & 5 & 4 & 3 & 5 & 4 & 3 & 5 & 400 & 3 & 4 & 0.64 \\
\hline $\begin{array}{l}\text { CPB time } \\
(\mathrm{min})\end{array}$ & 104 & 82 & 138 & 109 & 84 & 150 & 93 & 66 & 148 & 99 & 83.5 & 130 & 0.59 \\
\hline $\begin{array}{l}\text { CCT time } \\
(\mathrm{min})\end{array}$ & 65.5 & 43 & 104 & 60 & 44 & 95 & 50 & 32 & 73 & 60 & 44 & 83.5 & 0.44 \\
\hline $\mathrm{ET}(\min )$ & 390 & 300 & 600 & 360 & 300 & 600 & 360 & 285 & 720 & 390 & 300 & 480 & 0.91 \\
\hline ICDT & 3 & 3 & 4.5 & 4 & 3 & 5 & 3 & 3 & 4 & 4 & 3 & 5 & 0.55 \\
\hline OT (min) & 255 & 220 & 290 & 230 & 210 & 240 & 220 & 192 & 285 & 240 & 210 & 300 & 0.12 \\
\hline
\end{tabular}

Kruskal-Wallis $\mathrm{H}$ test; a:0,05; CPB, cardio pulmonary bypass; CCT, cross-clamp time; ET, extubation time; ICDT, intensive care day time; OT, operation time.

Postoperative dopamine use was higher in blood groups $A, B$, and $O$ than its intraoperative use $(p=0.001, p=0.014$, and $\mathrm{p}=0.001$, respectively). Postoperative norepinephrine use was higher in blood groups A, B, and $\mathrm{O}$ than its intraope- rative use ( $\mathrm{p}=0.001, \mathrm{p}=0.025$, and $\mathrm{p}=0.002$, respectively). Postoperative nitroglycerin use was higher in blood group $\mathrm{O}$ as compared to its intraoperative use $(\mathrm{p}=0.034)$ (Table 4). 
Table 4. Intraoperative and postoperative comparisons of inotropic agents ( $\mathrm{mg}$ ) used according to blood groups

\begin{tabular}{|c|c|c|c|c|c|c|c|c|c|c|c|c|c|}
\hline & \multicolumn{12}{|c|}{ Blood groups } & \multirow[b]{3}{*}{$\mathbf{P}$} \\
\hline & \multicolumn{3}{|l|}{$A(n=84)$} & \multicolumn{3}{|c|}{ B $(n=32)$} & \multicolumn{3}{|c|}{$A B(n=11)$} & \multicolumn{3}{|l|}{$0(n=65)$} & \\
\hline & Median & Q1 & Q3 & Median & Q1 & Q3 & Median & Q1 & Q3 & Median & Q1 & Q3 & \\
\hline $\begin{array}{l}\text { Intraoperative } \\
\text { dopamine }\end{array}$ & 28.00 & 12.00 & 44.00 & 29.04 & 12.00 & 41.30 & 11.80 & 6.00 & 24.00 & 24.00 & 16.00 & 40.00 & $0.287^{\mathrm{a}}$ \\
\hline $\begin{array}{l}\text { Postoperative } \\
\text { dopamine }\end{array}$ & 61.15 & 14.400 & 144.000 & 39.550 & 18.600 & 90.450 & 23.200 & .00 & 111.000 & 42.150 & 20.900 & 92.250 & $0.273^{a}$ \\
\hline $\mathbf{p}^{\mathrm{b}}$ & \multicolumn{3}{|l|}{$0.001^{\mathrm{b} *}$} & \multicolumn{3}{|l|}{$0.014^{b *}$} & \multicolumn{3}{|l|}{$0.327^{b}$} & \multicolumn{3}{|l|}{$0.001^{\mathrm{b} *}$} & \\
\hline $\begin{array}{l}\text { Intraoperative } \\
\text { norepinephrine }\end{array}$ & .300 & .060 & .720 & .190 & .054 & .500 & .225 & .120 & .480 & .280 & .080 & .678 & $0.919^{a}$ \\
\hline $\begin{array}{l}\text { Postoperative } \\
\text { norepinephrine }\end{array}$ & 3.150 & .000 & 24.000 & .306 & .000 & 12.700 & 1.560 & .000 & 13.500 & .240 & .000 & 14.800 & $0.324^{a}$ \\
\hline $\mathbf{p}$ & \multicolumn{3}{|l|}{$0.001^{b *}$} & \multicolumn{3}{|l|}{$0.025^{\llcorner *}$} & \multicolumn{3}{|l|}{$0,051^{\mathrm{b}}$} & \multicolumn{3}{|l|}{$\mathbf{0 . 0 0 2}^{\mathrm{b} *}$} & \\
\hline $\begin{array}{l}\text { Intraoperative } \\
\text { dobutamine }\end{array}$ & .00 & .00 & .00 & .00 & .00 & .00 & .00 & .00 & .00 & .00 & .00 & .00 & $0.646^{a}$ \\
\hline $\begin{array}{l}\text { Postoperative } \\
\text { dobutamine }\end{array}$ & .00 & .00 & .00 & .00 & .00 & .00 & .00 & .00 & .00 & .00 & .00 & .00 & $0.097^{\mathrm{a}}$ \\
\hline $\mathrm{p}$ & \multicolumn{3}{|l|}{$0.181^{b}$} & \multicolumn{3}{|l|}{$0.500^{\mathrm{b}}$} & \multicolumn{3}{|l|}{$0.317^{b}$} & \multicolumn{3}{|l|}{$0.484^{\mathrm{b}}$} & \\
\hline $\begin{array}{l}\text { Intraoperative } \\
\text { epinephrine }\end{array}$ & .00 & .00 & .00 & .00 & .00 & .00 & .00 & .00 & .00 & .00 & .00 & .00 & $0.698^{a}$ \\
\hline $\begin{array}{l}\text { Postoperative } \\
\text { epinephrine }\end{array}$ & .0 & .0 & .0 & .0 & .0 & .0 & .0 & .0 & .0 & .0 & .0 & .0 & $0.270^{a}$ \\
\hline $\mathrm{p}$ & \multicolumn{3}{|l|}{$1.00^{\mathrm{b}}$} & \multicolumn{3}{|l|}{$1.00^{\mathrm{b}}$} & \multicolumn{3}{|l|}{$0.317^{b}$} & \multicolumn{3}{|l|}{$0.715^{b}$} & \\
\hline $\begin{array}{l}\text { Intraoperative } \\
\text { nitroglycerin }\end{array}$ & 3.00 & 1.50 & 5.50 & 2.50 & 1.25 & 4.35 & 2.50 & 1.00 & 4.00 & 3.80 & 2.20 & 6.60 & $0.184^{a}$ \\
\hline $\begin{array}{l}\text { Postoperative } \\
\text { nitroglycerin }\end{array}$ & 1.00 & .00 & 15.80 & .00 & .00 & 17.60 & 1.50 & .00 & 7.80 & 4.55 & .00 & 16.25 & $0.530^{a}$ \\
\hline $\mathrm{p}$ & \multicolumn{3}{|l|}{$0.315^{b}$} & \multicolumn{3}{|l|}{$0.107^{b}$} & \multicolumn{3}{|l|}{$0.407^{b}$} & \multicolumn{3}{|l|}{$0.034^{b *}$} & \\
\hline
\end{tabular}

There was no difference among $\mathrm{RH}$ blood groups in terms of use of fentanyl and demizolam, CPB time, cross-clamp time, postoperative intubation time, intensive care hospitalization time, and operation time (Table 5).

The use of postoperative dopamine, norepinephrine, and nitroglycerine was higher in the $\mathrm{Rh}(+)$ group than their intraoperative use $(\mathrm{p}=0.001, \mathrm{p}=0.001$, and $\mathrm{p}=0.011$, respectively). Postoperative norepinephrine use was higher in the $\mathrm{Rh}(-)$ group than in its intraoperative use (0.004). The use of intraoperative nitroglycerin in the $\mathrm{Rh}(+)$ group was higher than in the Rh (-) group $(\mathrm{p}=0.042)$ (Table 6).

\section{DISCUSSION}

Our study demonstrated that postoperative use of dopamine and norepinephrine was higher in blood groups A, B, and $\mathrm{O}$ than its intraoperative use. Postoperative use of nitroglycerin was higher in blood group $\mathrm{O}$ than its intraoperative use. Postoperative uses of dopamine, norepinephrine, and nitroglycerin was higher in the Rh (+) blood group than in intraoperative use. Postoperative norepinephrine use was higher in the Rh (-) blood group than in its intraoperative use.
Intraoperative nitroglycerin use was more in $\mathrm{Rh}(+)$ blood group than in Rh (-) blood group.

Although different studies have been conducted about the blood group, as far as we know, our study is the first one in the literature to demonstrate the use of intraoperative and postoperative inotropic agents of different blood groups in adult cardiac surgery. A study that was conducted to determine the anesthetic effects of propofol among blood groups demonstrated that the measured values of mean arterial pressure and heart rate were higher in the patients with blood group B. Moreover, the bispectral index values were higher in patients with blood group A (12). Another study showed that after the placement of left ventricular assist device, there was no significant difference in blood transfusions between blood group $\mathrm{O}$ and non-O blood group in the intraoperative and postoperative periods between 7 and 90 days. In addition, there was no significant difference in the hematocrit values during the implantation of chest tube in the first 24 hours or within the first 48 hours after surgery (3). A Nordic cohort study that was conducted on patients with acute type A aortic dissection demonstrated there was no association 


\begin{tabular}{|c|c|c|c|c|c|c|c|}
\hline & \multicolumn{6}{|l|}{$\mathbf{R h}$} & \multirow[b]{3}{*}{$\mathbf{p}$} \\
\hline & \multicolumn{3}{|c|}{$\operatorname{Rh}(+)(n=174)$} & \multicolumn{3}{|c|}{ Rh (-) $(n=18)$} & \\
\hline & Median & Q1 & Q3 & Median & Q1 & Q3 & \\
\hline $\begin{array}{l}\text { Fentanyl induction } \\
(\mathrm{mcg})\end{array}$ & 250.00 & 200.00 & 350.00 & 275.00 & 200.00 & 425.00 & 0.773 \\
\hline $\begin{array}{l}\text { Demizolam induction } \\
(\mathrm{mg})\end{array}$ & 4.00 & 3.00 & 5.00 & 4.00 & 3.00 & 4.00 & 0.721 \\
\hline CPB time (min) & 101.00 & 82.00 & 133.00 & 127.50 & 88.00 & 181.00 & 0.080 \\
\hline CCT (min) & 60.00 & 43.00 & 90.00 & 74.00 & 49.00 & 147.00 & 0.095 \\
\hline ET (min) & 390.00 & 300.00 & 540.00 & 360.00 & 300.00 & 420.00 & 0.399 \\
\hline ICDT & 3.50 & 3.00 & 5.00 & 3.00 & 3.00 & 4.00 & 0.365 \\
\hline OT (min) & 240 & 210 & 285 & 284 & 210 & 330 & 0,113 \\
\hline
\end{tabular}

Mann-Whitney U test; $\mathrm{CPB}$, cardio pulmonary bypass; CCT, cross-clamp time; ET, extubation time; ICDT, intensive care day time; OT, operation time

\section{Table 6. Intraoperative and postoperative comparison of inotropic agents used according to Rh blood groups}

\begin{tabular}{|c|c|c|c|c|c|c|c|}
\hline & \multicolumn{6}{|l|}{$\mathbf{R h}$} & \multirow[b]{3}{*}{$\mathbf{P}$} \\
\hline & \multicolumn{3}{|c|}{$\operatorname{Rh}(+)(n=174)$} & \multicolumn{3}{|c|}{ Rh (-) (n=18) } & \\
\hline & Median & Q1 & Q3 & Median & Q1 & Q3 & \\
\hline Intraoperative dopamine & 24.00 & 12.00 & 40.00 & 34.00 & 21.00 & 43.50 & $0.215^{\mathrm{a}}$ \\
\hline Postoperative dopamine (mg) & 43.400 & 14.400 & 126.000 & 48.150 & 21.900 & 140.000 & $0.750^{\mathrm{a}}$ \\
\hline $\mathbf{p}$ & \multicolumn{3}{|l|}{$0.001^{\mathrm{b} *}$} & \multicolumn{3}{|l|}{$0.148^{\mathrm{b}}$} & \\
\hline $\begin{array}{l}\text { Intraoperative norepinephrine } \\
(\mathrm{mg})\end{array}$ & .280 & .080 & .645 & .290 & .090 & .745 & $0.720^{\mathrm{a}}$ \\
\hline $\begin{array}{l}\text { Postoperative norepinephrine } \\
\text { (mg) }\end{array}$ & .800 & .000 & 16.900 & 2.400 & .360 & 13.500 & $0.334^{\mathrm{a}}$ \\
\hline $\mathbf{p}$ & \multicolumn{3}{|l|}{$0.0011^{\mathrm{b}} *$} & \multicolumn{3}{|l|}{$0.004^{\mathrm{b}} *$} & \\
\hline İntraoperative dobutamine & .00 & .00 & .00 & .00 & .00 & .00 & $0.277^{\mathrm{a}}$ \\
\hline $\begin{array}{l}\text { Postoperative dobutamine } \\
(\mathrm{mg})\end{array}$ & .00 & .00 & .00 & .00 & .00 & .00 & $0.904^{\mathrm{a}}$ \\
\hline $\mathbf{p}$ & \multicolumn{3}{|l|}{$0.249^{b}$} & \multicolumn{3}{|l|}{$0.180^{b}$} & \\
\hline Intraoperative epinephrine & .00 & .00 & .00 & .00 & .00 & .00 & $0.411^{\mathrm{a}}$ \\
\hline Postoperative epinephrine(mg) & .00 & .00 & .00 & .00 & .00 & .00 & $0.263^{\mathrm{a}}$ \\
\hline $\mathbf{p}$ & \multicolumn{3}{|l|}{$0.735^{b}$} & \multicolumn{3}{|l|}{$0.317^{b}$} & \\
\hline $\begin{array}{l}\text { İntraoperative nitroglycerin } \\
(\mathrm{mg})\end{array}$ & 3.16 & 1.61 & 5.55 & 2.00 & .00 & 3.39 & $0.042^{a} *$ \\
\hline $\begin{array}{l}\text { Postoperative nitroglycerin } \\
(\mathrm{mg})\end{array}$ & 2.15 & .00 & 16.40 & 1.00 & .00 & 9.00 & $0.558^{a}$ \\
\hline $\mathbf{p}$ & \multicolumn{3}{|l|}{0.011 b * } & \multicolumn{3}{|l|}{$0.363^{\mathrm{b}}$} & \\
\hline
\end{tabular}

among surgical incidence, postoperative complications, and survival among the ABO blood groups (13). Komatsu et al, showed that there was no increase in postoperative blood loss in blood group $\mathrm{O}$, and less erythrocytes (RBC) transfusions were required intraoperatively in blood group $\mathrm{O}$ than the non-O blood group (14). Contrary to this study, Mazzeffi et al, showed that in 111 patients who underwent extracorpo- real membrane oxygenation, erythrocytes (RBC) transfusion in individuals with blood group $\mathrm{O}$ needed a higher rate of transfusion than non-O blood group individuals (15). Patients with blood group $\mathrm{O}$ were more likely to develop bleeding complications (16).

It is known that dopaminergic and noradrenergic systems play vital roles in addiction, drug abuse, impulsivity, 
and socially unacceptable behavior (17-18). Some studies have showed that subjects with blood group $\mathrm{O}$ have produced more norepinephrine than subjects with other ABO blood groups (17). A study that investigated the correlation between blood groups and opioid addiction revealed that there was a relationship between D2 receptors and psychoactive substance dependence. Moreover, this study showed that the frequency of the A1A1 genotype was significantly higher among people with opium addiction (19). Another study that investigated the relationship between psychiatric disorders and $\mathrm{ABO}$ blood groups showed an patients belonging the blood group $\mathrm{AB}$ have an increased tendency to develop psychiatric disorders (5). Rinieris et al, pointed out that there is a negative relationship between blood group A and bipolar affective disorder (20). Another study found a relationship between blood group A and unipolar depression (21). A different study found difference in the incidence of cancer in different blood groups (22). A group of researchers found reduction in the risk of esophageal carcinoma (EC) in individuals with blood group $\mathrm{O}$ (23). Patients with blood group $\mathrm{B}$ had a higher risk of developing EC. However, there was no significant relationship between individuals with blood groups $\mathrm{A}$ and $\mathrm{AB}$ (24). Another study reported a positive relationship between blood group A and the risk of pancreatic cancer (25).

In December 2019, there was an outbreak of an unknown pneumonia epidemic in Wuhan, Hubei Province, China. Chinese scientists have confirmed that this outbreak was caused by a new virus. The World Health Organization named this disease as coronavirus disease 2019 (2019-nCoV or SARS-CoV-2 or COVID-19) (26). In this new COVID 19 , blood group A was associated with an increased risk for infection, whereas blood group $\mathrm{O}$ was associated with a reduced risk (27).

Limitations of our study: The different number of cases in the blood groups and the retrospective nature of this study constitute the two major limitations of our study.

As a conclusion, It has been observed in studies that some diseases occur more frequently in different blood groups. The uses of blood transfusion and inotropic agents are very common in $\mathrm{CPB}$ surgeries. In our study, we observed a difference in the use of inotropic agents in $\mathrm{ABO}$ and $\mathrm{Rh}$ blood groups.

\section{Acknowledgment}

Included as a e-oral presentation at the 26 National E-Congress of Turkey's Chest Cardiovascular Anesthesia and Intensive Care Association. 17-18 September 17-18/2020.

The authors would like to thank Enago (www.enago.com) for the English language review.

Conflict of interest: None

\section{Financial support: None}

Research Contribution Rate Statement Summary: The authors declare that, they have contributed equally to the manuscript.

\section{REFERENCES}

1. Guyton AC, Hall JE. Blood Types; Transfusion;Tissue and Organ Trans- plantation. In: Guyton AC, Hall JE, editors. Textbook of Medical Physiology. Philedelphia: W.B. Saunders. 2006;45253.

2. Storry JR, Castilho L, Daniels G, Flegel WA, Garratty G, de Haas M. International Society of Blood Group Terminology: Cancun Report (2012). Vox Sang 2013; 107: 90-6.

3. Sun GH, Bruguera C, Saadat S, Moss D, Schumann R, Welsby IJ, et al. ABO Blood Group and Transfusions In the Intraoperative and Postoperative Period After LVAD Implantation. Journal of Cardiothoracic and Vascular Anesthesia 2019; 000: 1-6.

4. Bilgen H. Kan grup Antijenleri. İ.Ü. Cerrahpaşa Tip Fakültesi Sürekli Tip Eğitimi Etkinlikleri. Herkes için Transfüzyon Tibbı Sempozyum Dizisi No: 44:55-65, 2005.

5. Pisk SV, Vuk T, Ivezić E, Irena Jukić, Jasna Bingulac-Popović, Igor Filipčić. $\mathrm{ABO}$ blood groups and psychiatric disorders: a Croatian study. Blood Transfus 2019; 17: 66-71.

6. Stamatakos M, Kontzoglou K, Safioleas C, Safioleas C, Manti C, Safioleas M. Breast cancer incidence in Greek women in relation to ABO blood groups and RH factor. Int Semin Surg Oncol 2009; 6: 14.

7. Franchini M, Favaloro EJ, Targher G, Lippi G. ABO blood group, hypercoagulability, and cardiovascular and cancer risk. Crit Rev Clin Lab Sci 2012; 49: 137-49.

8. Jukic I, Bingulac-Popovic J, Dogic V, Hecimovic A, Babic I, Batarilo I. Evaluation of ABO blood groups as a risk factor for myocardial infarction. Blood Transfus 2012; 29: 1-2.

9. St. Andre' AC, DelRossi A. Hemodynamic management of patients in the first 24 hours after cardiac surgery. Crit Care Med 2005; 33: 2082-93.

10. M. Müller, A. Junger, M. Brau, Kwapisz M.M, E. Schindler, $\mathrm{H}$. Akintiirk et al. Incidence and risk calculation of inotropic support in patients undergoing cardiac surgery with cardiopulmonary bypass using an automated anaesthesia recordkeeping system. Br J Anaesth 2002; 89: 398-404.

11. Ahmed I, House CM, Nelson WB. Predictors of inotrope use in patients undergoing concomitant coronary artery bypass graft (CABG) and aortic valve replacement (AVR) surgeries at separation from cardiopulmonary bypass (CPB). J Cardiothorac Surg 2009; 4: 24

12. Du Y, Shi H, Yu J. Comparison in anesthetic effects of propofol among patients with different $\mathrm{ABO}$ blood groups. Medicine 2017; 96: 20.

13. Nozohoor S, Ahmad K, Bjurbom M, Hansson EC, Heimisdottir A, Jeppssone A, et al. ABO blood group does not impact incidence or outcomes of surgery for acute type A aortic dissection. Scandinavian cardiovascular journal 2019; 54:2, 124-129.

14. Komatsu R, Dalton JE, Ghobrial M, Fu AY, Lee JH, Egan C, et al. Blood type $\mathrm{O}$ is not associated with increased blood loss in extensive spine surgery. J Clin Anesth 2014; 26: 432-7.

15. Mazzeffi M, Gupta R, Lonergan T, Pasrija C, Kon Z, Tanaka K. $\mathrm{ABO}$ type and bleeding during adult ECMO. Intensive Care Med 2017; 43: 275-6.

16. Horwich I, Evans DA, Mc Connell RB, W T Donohoe. ABO blood groups in gastric bleeding, Gut 1966; 7: 680-5.

17. D’Adamo P, Whitney CH. Live Right 4 Your Type: 4 Blood Types, 4 Program-The Individualized Prescription for Maximizing Health, Metabolism, and Vitality in Every Stage of Your Life. Berkley: GP Putnam \& Sons, 2001. 
18. McRae-Clark AL, Cason AM, Kohtz AS, Santa-Maria MM, Jones GA , Brady KT,. Impact of Gender on Corticotropin-Releasing Factor and Noradrenergic Sensitivity in Cocaine Use Disorder. J Neurosci Res 2017; 95: 320-7.

19. Aflatoonian MR, Meymandi MS, Divsalar K, Mahmoudi M, Heravi G. Possible association between human blood types and opioid addiction. Am J Addict 2011; 20: 581-4.

20. Rinieris PM, Stefanis CN, Lykouras EP, Varsou EK. Affective disorders and blood types. Acta Psychiatr Scand 1979; 60: 272-8.

21. Shapiro W, Rafaelsen OJ, Ryder LP, Svejgaard A, Sorensen H. $\mathrm{ABO}$ blood groups in unipolar and bipolar manic-depressive patients. Am J Psychiatr 1977; 134: 197-200.

22. Aird I, Bentall HH, Roberts JA. A relationship between cancer of stomach and the ABO blood groups. Br Med J 1953; 1(4814): 799-801.

23. Le Pendu J, Marionneau S, Cailleau-Thomas A, Rocher J, Le Moullac-Vaidye B, Clement M. ABH and Lewis histoblood group antigens in cancer. APMIS: acta pathologica, microbiologica, et immunologica Scandinavica 2001;

24. Wang W, Liu L, Wang Z, Lu X, Wei M, Lin T, et al ABO blood group and esophageal carcinoma risk: from a case-control study in Chinese population to meta-analysis. Cancer Causes Control 2014 25:1369-77.

25. Risch HA, Lu L, Wang J, Zhang W, Ni Q, Gao YT et al. ABO blood group and risk of pancreatic cancer: a study in shanghai and meta-analysis. Am J Epidemiol 2013; 177: 1326-37.

26. Peng PW, Ho PL, Hota SS. Outbreak of a new coronavirus: what anesthetists should know. British Journal of Anaesthesia 2020. doi.org/10.1016/j.bja.2020.02.008.

27. Zhao J, Yang Y, Huang HP, Li D, Gu DF, Lu XF, et al. Relationship between the ABO Blood Group and the COVID-19 Susceptibility.BMJ Yale MedR xiv. doi.org/10.1101/2020.03.11.200310 96. 